\title{
Factors Influencing the Implementation of Environmental Management Systems in Ghanaian Firms
}

\author{
Samuel Famiyeh (Corresponding author) \\ GIMPA Business School, Ghana Institute of Management and Public Administration \\ P.O. Box. AH 50, Achimota, Accra, Ghana \\ Tel: 233-214-010-681Ｅ-mail: sfamiyeh@gimpa.edu.gh
}

Saint Kuttu

GIMPA Business School, Ghana Institute of Management and Public Administration P.O. Box. AH 50, Achimota, Accra, Ghana

Tel: 233-214-010-681_E-mail: skuttu@gimpa.edu.gh

Ebenezer Bugri Anarfo

GIMPA Business School, Ghana Institute of Management and Public Administration

P.O. Box. AH 50, Achimota, Accra, Ghana

Tel: 233-214-010-681Ｅ-mail: ebugri@yahoo.com

Received: May 16, 2014 Accepted: May 30, 2014

doi:10.5296/emsd.v3i2.5893 URL: http://dx.doi.org/10.5296/emsd.v3i2.5893

\begin{abstract}
This paper investigates the driving forces of environmental management systems implementation in Ghana. Structured questionnaire was used to target environmental, health, safety, operations, administrative officers and managers. In all, fifty three respondents were surveyed and the results show that the top issues driving the implementation of environmental management systems in Ghana in order of importance based on their mean values on a five-
\end{abstract}


point Likert scale were: operational benefits (4.44), marketing opportunities (4.23), public relation/image (4.18), conservation of natural resources (4.17), potential cost savings (4.16) and competition (4.13). Pressure from employees and customers seems to have little or no influence as far as the implementation of environmental management system is concern recording a mean value of 3.02. This indicates the need for organizations that have implemented environmental management systems in their operations to catalogue the operational benefits and the other opportunities gained in order to attract other firms to implement this system. It is also essential for intensive internal awareness programmes for employees to be well informed on the benefits of environmental management systems in order to be motivated during its planning and implementation.

The study considered only ten key factors that drive environmental management system implementation. Future studies can also look at the support of top management as well as the challenges they face in implementing environmental management systems.

Keywords: Ghana, EMS, Driving forces, Environmental, Management, Systems

\section{Introduction}

Environmental Management System (EMS) has developed within organizations over the past decade as firms keeps on identifying means to address changing environmental issues. Currently, many firms have recognized that meeting the regulatory requirements was not adequate for staying in the competition and have now turned efforts to pollution prevention and monitoring for effective and efficient operations (Hoffman, 1994; Yosie and Herbst, 1996; Watson et al., 2004). The general basis for an EMS is to write how a task with an environmental impact is to be done, do the task as it is written, and check periodically to verify that the task is being done as intended and, if not, correct the problem (Wilson, 1998; Woodside et al. 1998; Cascio, 1996). EMS basically, involves the establishment of an environmental plan, the creation of goals to reduce environmental impacts, the implementation of appropriate actions, and some form of internal assessment or monitoring. The major aim of an EMS is to develop, implement, manage, coordinate and monitor environmental activities across an organisation. (Forbes and Anne De Silva, 2012)

Organizations implementing comprehensive environmental management system to reduce or eliminate environmental issues have gained internal and external benefits in terms of increasing the awareness amongst their employees, legal compliance and financial benefits through savings in consumption of utilities (Ann et al., 2006). Melnyk et al. (2003) stated that an EMS plays a critical role in terms of improvement to an organisation's environmental performance and also to its overall performance. The benefits that can be gained through implementation of an EMS may include improved regulatory compliance, decreased waste materials, reduced pollution emissions, enhanced corporate image (Ann et al., 2006), improved production efficiencies, increased customer satisfaction, access to new markets, and increased profits (Darnall et al., 2008; Potoski and Prakash, 2005; Stapleton et al., 2001; Chavan 2005).

Whilst there is considerable research works examining the drivers which are encouraging companies to implement an EMS (Barber et al., 2009; Forbes et al., 2009; Gabzdylova et al., 
2009; Hughey et al., 2005; Warner, 2007) in the developed countries in order to achieve more voluntary adoption and implementation, little research have been conducted in the developing countries to understand these drivers. Research into the issues of Environmental Management Systems in Ghana has been very scanty; most of the research works focuses more on natural resource use and management (Krystof, et, al 2014; Tweneboah and Bentil 2014). Given the importance of the role the private sector plays in production in the Ghanaian economy and the numerous issues related to industrial pollution and waste, it is surprising that relatively little research has been undertaken in this field (Ayirebi-Dansoh, et, al 2010 and Ayarkwa 2010). This suggests the need for effective environmental management to manage the resources consumed in production, as well as, management of residues from production activities. The purpose of this paper is to identify factors influencing the implementation of environmental management systems in Ghana.

The rest of this paper is structured as follows: First, the paper presents a summary of the relevant literature pertaining to driving forces as far as the implementation of environmental management systems are concerned. Second, the proposed theory and methodology are outlined, explaining all the variables, and the method of measurement. Third, sample characteristics and the analysis are put forward. This is followed by the study's limitations and potential future research directions. Finally, the implications and conclusions are presented.

\section{Literature Review}

An environmental management system is one of the tools which firms can use to voluntarily implement environmental policy. An EMS consists of "a number of interrelated elements that function together to help a firm manage, measure, and improve the environmental aspects of its operations" (Welford ed., 1996). An EMS is a continual cycle of planning, implementing, reviewing and improving the processes and actions that an organization undertakes to meet its business and environmental goals (USEPA, 2003). An EMS is thus defined as any formal approach to improving the environmental performance of an organisation through the integration of environmental concerns into an overall management system (Hamner, 2001).

Many firms pursue ISO 14001 certification in response to peer pressure (Clark, 1999) in order to improve risk management and lower their liabilities (Graff, 1997) harmonize standards with ISO 9000 (Litskas, 1999), reduce inspection frequency and improve bottom line performance by enhancing internal efficiencies (Clark, 1999; Graff, 1997; Litskas, 1999;, Tibor, and Ira, 1996; Gyula Vastag, 2003). Organisations can improve public relations and corporate image and document control by ISO 14001 certification (Litskas, 1999), respond more effectively to increased customer pressure (Clark, 1999; Graff, 1997; Litskas, 1999), compete more easily abroad (Graff, 1997; Litskas, 1999) and enhance the quality of their supply chains (Graff, 1997).

Implementation of an Environmental Management System can provide several economic and non-economic benefits for organisations (Potoski and Prakash, 2005). According to Melnyk et al. (2003), organizations implementing EMS can have improvement in terms of environmental as well as overall performance. Other benefits that can be achieved through the implementation of an EMS may include: improved regulatory compliance, decreased waste materials, reduced 
pollution emissions, enhanced corporate image, improved production efficiencies, increased customer satisfaction, access to new markets, and increased profits (Darnall et al., 2008; Potoski and Prakash, 2005; Stapleton et al., 2001). Additional benefits through the implementation of a formal certified EMS includes reduced overall costs, reduced lead times, improved position in the marketplace, enhanced company reputation, better product design/development, and improved opportunities for selling products in international markets (Melnyk et al., 2003). Andrews et al., 1999 also reported benefits such as heightened awareness of environmental issues among employees, a shared vision for addressing these issues, and associated increases in employee morale. The associated internal benefits are, improved quality of management, training and environmental information; cost savings from improved material, energy and waste efficiencies; and increased employee motivation, morale and skills. External benefits included gaining new customers or competitive advantage, staying in businesses, assured legal compliance, increased energy efficiencies and recycling, reduced pollution, a more positive public image, better customer relationships, and improved co-operation and communication with stakeholders (Hillary, 2004).

\section{Materials and Methods}

The study was conducted using a structured questionnaire. The target population was environmental, health, safety, operations, administrative officers and managers who are major environmental decision makers when it comes to pollution issues relating to their firms. Highly experienced group of experts in administration, operations, marketing, occupational health, safety and environmental management who were on a special programme in occupational safety, health and environmental management in one of the top business schools in Ghana were interesting and appropriate population to study because of their unique characteristics.

The questionnaires were administered and completed in the classroom. A total of 55 questionnaires were distributed but only 53 were usable. Confidentiality of responses was emphasized in the cover letter with the title 'confidential survey' and in the text. Before embarking on the data collection, two environmental experts were first invited to assess the instrument. Issues of importance in the questionnaire were:

- The number of years respondents have been working with their organizations;

- The number of years their organizations have been operating;

- Their respective departments and industry;

- Respondents familiarity with environmental management systems; and

- The driving forces of environmental management systems implementation.

The conceptual model used was derived from Melnyk et al. 2003, Darnall et al., 2008; Potoski and Prakash, 2005; and Stapleton et al., 2001. For the purposes of this study, the authors wanted to gain a 'deep understanding' of the perceived driving forces attributable to Environmental Management System (EMS) or Environmental Management Plan implementation (EMP as referred to by the Ghana EPA) based on a survey. The analytical techniques and procedures used were similar to those adapted by Famiyeh, Kuttu and Bugri, 2014 in assessing the 


\section{Macrothink}

Environmental Management and Sustainable Development

ISSN 2164-7682

2014, Vol. 3, No. 2

challenges of environmental management systems implementation in Ghanaian firms.

\section{Statistical Analysis of the Questionnaire Data Using SPSS}

\subsection{Background Information of Respondent and Organizations Surveyed}

Table 1. Number of years respondents organizations have been in operation

\begin{tabular}{|c|c|c|c|c|c|}
\hline & & Frequency & Percent & Valid Percent & Cumulative Percent \\
\hline \multirow{5}{*}{ Valid } & 5 years or less & 10 & 18.9 & 18.9 & 18.9 \\
\cline { 2 - 6 } & $6-10$ yrs & 6 & 11.3 & 11.3 & 30.2 \\
\cline { 2 - 6 } & $11-15$ yrs & 9 & 17.0 & 17.0 & 47.2 \\
\cline { 2 - 6 } & 16 yrs or above & 28 & 52.8 & 52.8 & 100.0 \\
\cline { 2 - 6 } & Total & 53 & 100.0 & 100.0 & \\
\hline
\end{tabular}

In all fifty three officers/managers were surveyed in this study. Table 1 shows that out of fifty three respondents, ten of them indicated that their organization have been in operation for less than 5 years, six of them indicated 6 to 10 years, 9 indicated 11 to 15 years and 28 of them indicated over sixteen (16) years representing $18.9 \%, 11.3 \%, 17.0 \%$ and $52.8 \%$ respectively. This shows that majority of the organizations surveyed seems to have been in existence for more than six years.

\subsection{Department of Respondents}

Table 2. Respondents Departments

\begin{tabular}{|c|c|c|c|c|c|}
\hline & & Frequency & Percent & Valid Percent & Cumulative Percent \\
\hline \multirow{5}{*}{ Valid } & Administration & 2 & 3.8 & 3.8 & 3.8 \\
\cline { 2 - 6 } & Operations & 15 & 28.3 & 28.3 & 32.1 \\
\cline { 2 - 6 } & HSE & 21 & 39.6 & 39.6 & 71.7 \\
\cline { 2 - 6 } & Marketing & 3 & 5.7 & 5.7 & 77.4 \\
\cline { 2 - 6 } & Other & 12 & 22.6 & 22.6 & 100.0 \\
\cline { 2 - 6 } & Total & 53 & 100.0 & 100.0 & \\
\hline
\end{tabular}

Table 2 present the various departments of respondents. Respondents belong to four key departments; viz. administration, operations, marketing, health, safety and environment. In all there were 2, 15, 21, and 3 respondents working with Administration, operations, Marketing, Health, Safety and Environment representing 3.8\%, 28.8\%, 39.6\% and 5.7\% respectively. Twelve of the respondents representing 22.6 percent indicated that they were working in departments other than the above. 


\subsection{Industrial Sector of Respondents}

Table 3. Industrial Sector of Respondents

\begin{tabular}{|c|c|c|c|c|c|}
\hline & Frequency & Percent & Valid Percent & Cumulative Percent \\
\hline \multirow{7}{*}{ mining } & 15 & 28.3 & 28.3 & 28.3 \\
\cline { 2 - 6 } & energy & 3 & 5.7 & 5.7 & 34.0 \\
\cline { 2 - 6 } & chemical and paints & 3 & 5.7 & 5.7 & 39.6 \\
\cline { 2 - 6 } & pharmaceuticals & 1 & 1.9 & 1.9 & 41.5 \\
\cline { 2 - 6 } & food & 2 & 3.8 & 3.8 & 45.3 \\
\cline { 2 - 6 } & financial institution & 2 & 3.8 & 3.8 & 49.1 \\
\cline { 2 - 6 } & education & 4 & 7.5 & 7.5 & 56.6 \\
\cline { 2 - 6 } & construction & 3 & 5.7 & 5.7 & 62.3 \\
\cline { 2 - 6 } & Health & 5 & 9.4 & 9.4 & 71.7 \\
\cline { 2 - 6 } & agriculture & 1 & 1.9 & 1.9 & 73.6 \\
\cline { 2 - 6 } & other & 14 & 26.4 & 26.4 & 100.0 \\
\cline { 2 - 6 } & Total & 53 & 100.0 & 100.0 & \\
\hline
\end{tabular}

The respondents were asked to indicate the industrial sector of their respective organizations. The key sectors which participated in the survey were: Mining, energy, chemical/paints, pharmaceuticals, food, financial institution, education, construction, health and agriculture. The highest number of participants came from the mining sector, scoring $28.3 \%$. The details of the various sectors are presented in the frequency Table 3.

\subsection{Respondents'Awareness of Environmental Management System (EMS)}

Table 4. Respondents awareness of environmental management systems

\begin{tabular}{|c|c|c|c|c|c|}
\hline \multicolumn{6}{|c|}{ (EMS) } \\
\hline \multirow{3}{*}{ Valid } & & Frequency & Percent & Valid Percent & Cumulative Percent \\
\hline & Yes & 49 & 92.5 & 96.1 & 96.1 \\
\cline { 2 - 7 } & No & 2 & 3.8 & 3.9 & 100.0 \\
\cline { 2 - 7 } & Total & 51 & 96.2 & 100.0 & \\
\hline \multicolumn{2}{|c|}{ Missing System } & 2 & 3.8 & & \\
\hline \multicolumn{2}{|c|}{ Total } & 53 & 100.0 & & \\
\hline
\end{tabular}

In this part of the survey, the respondents were asked whether they were familiar with Environmental Management Systems (EMS). Forty nine of the respondents representing 92.1\% of the total indicated that they were familiar with Environmental Management Systems and only two of them representing 3.8\% indicated they were not familiar with Environmental Management Systems. This is presented in Table 4. The missing system represents questions unanswered.

\subsection{Driving Forces of Environmental Management Systems Implementation}

\subsubsection{Descriptive Analysis}

This study seeks to examine the factors acting as driving forces in the implementation of 
environmental management system (EMS) in organizations in Ghana. Factors that were identified as driving forces in the implementation of EMS in this study included: low insurance premiums, competition, potential for cost savings, pressure from regulatory bodies, conservation of natural resources, pressure from employees/customers, public relations/corporate image, enhance quality of supply chains, marketing opportunities and operational benefits. The driving forces were rated on a five point Likert scale $(1=$ strongly disagree, $2=$ disagree, $3=$ neutral $4=$ agree $5=$ strongly agree). These dimensions attempt to capture respondents' cognitive and effective evaluation of the forces that drives environmental management systems (EMS) Implementation.

Table 5. Descriptive Statistics of the Driving Forces using SPSS

\begin{tabular}{|c|c|c|c|c|c|}
\hline Variable & Observation & Mean & Std. Dev. & Minimum & Maximum \\
\hline LOWINS & 46 & 3.978 & 0.954 & 1 & 5 \\
\hline DUECOM & 51 & 4.137 & 0.960 & 2 & 5 \\
\hline POTCOS & 48 & 4.167 & 0.834 & 2 & 5 \\
\hline PREREG & 50 & 3.720 & 1.011 & 1 & 5 \\
\hline CONSERV & 45 & 4.178 & 1.007 & 2 & 5 \\
\hline PRESEMP & 49 & 3.021 & 1.216 & 1 & 5 \\
\hline PUBLIC & 48 & 4.188 & 0.915 & 2 & 5 \\
\hline ENHQUAS & 48 & 3.896 & 0.692 & 3 & 5 \\
\hline MARKOS & 48 & 4.234 & 0.692 & 3 & 5 \\
\hline OPERBEFS & 50 & 4.440 & 0.787 & 1 & 5 \\
\hline
\end{tabular}

LOWINS = low insurance premiums, DUECOM = due to competition, POTCOS =potential for cost savings, PREREG =pressure from regulatory bodies, CONSERV = conservation of natural resources, PRESEMP = pressure from employees/demand from customers, PUBLIC = public relation and corporate image, ENHQUAS = enhance quality of supply chains, MARKOS = marketing opportunities OPERBEFS = operational benefits

Table 5 presents the descriptive statistics of the various driving forces that influences the implementation of environmental management systems in Ghana. From the results, the six top most important forces driving the implementation of environmental management systems in Ghana in order of importance based on their mean values on a five point Likert scale were: operational benefits (4.44), marketing opportunities (4.23), public relation/image (4.18), conservation of natural resources (4.17), potential cost saving (4.16) and competition (4.13).

The next three important factors driving the implementation of environmental management system in Ghana are the achievement of low insurance premiums, enhancement of the quality of supply chains and the pressure from regulatory bodies having mean values of 3.97, 3.89 and 3.72 respectively. This is presented in table 5. Using a threshold mean value of 3.5 , the only factor which seems to have no influence as far as the implementation of an EMS is concerned, is the pressure from employees and customers. This had a mean value of 3.02. A mean value of 3.02 seems to demonstrate that all respondents were virtually neutral on pressure from employees and customers as a driving force for the implementation of environmental management system in Ghana. 


\subsubsection{Correlation Analysis Using SPSS}

Table 6. Pearson Correlation Matrix

\begin{tabular}{|c|c|c|c|c|c|c|c|c|c|c|}
\hline & LOWINS & DUECOM & POTCOS & PREREG & CONSERV & PRESEMP & PUBLIC & ENHQUAS & MARKOS & OPERBEFS \\
\hline LOWINS & 1 & & & & & & & & & \\
\hline DUECOM & 0.036 & 1 & & & & & & & & \\
\hline POTCOS & 0.364 & 0.241 & 1 & & & & & & & \\
\hline PREREG & 0.200 & 0.029 & 0.210 & 1 & & & & & & \\
\hline CONSERV & -0.020 & 0.157 & 0.203 & 0.277 & 1 & & & & & \\
\hline PRESEMP & 0.337 & 0.116 & 0.345 & 0.531 & 0.178 & 1 & & & & \\
\hline PUBLIC & 0.012 & 0.121 & 0.337 & -0.008 & 0.505 & 0.430 & 1 & & & \\
\hline ENHQUAS & 0.032 & 0.513 & 0.421 & 0.044 & 0.225 & 0.400 & 0.267 & 1 & & \\
\hline MARKOS & 0.089 & 0.634 & 0.220 & -0.133 & 0.025 & 0.225 & 0.298 & 0.476 & 1 & \\
\hline OPERBEFS & 0.199 & 0.136 & 0.397 & -0.114 & 0.361 & 0.0203 & 0.300 & 0.496 & 0.211 & 1 \\
\hline
\end{tabular}

LOWINS $=$ low insurance premiums, DUECOM $=$ due to competition, POTCOS =potential for cost savings, PREREG =pressure from regulatory bodies, CONSERV $=$ conservation of natural resources, PRESEMP $=$ pressure from employees/demand from customers, PUBLIC = public relation and corporate image, ENHQUAS = enhance quality of supply chains, MARKOS = marketing opportunities, OPERBEFS = operational benefits

Table 6 shows the Pearson correlation matrix between all the variables used in this study. From the table, there seems to be no problem of multicollineary among the variables. This is because all the correlation co-efficients are below 0.50 apart from competition and marketing opportunities (0.634), competition and enhances quality of supply chains (0.513), conservation of natural resources and public relations (0.505). Pressure from regulatory bodies and pressure from employees (0.531) also shows some multicollinearity problems among these variables but were not significant. This shows that all the variables used are all independent from each other and hence there is no problem of multicollineary.

\section{Discussions}

In assessing the driving forces of environmental management system implementation in Ghana, it was clear that, operational benefits (Smith, and Kemp, 1998; Hillary, 1998 and 2000), marketing opportunities (Darnall et al., 2008), public relations/corporate image (Darnall et al., 2008), conservation of natural resources (see. Potoski and Prakash, 2005) and the potential for cost savings, competition, low insurance premium (Darnall et al., 2008) and the enhancement of the quality of supply chains and the pressure from regulatory (Gallagher, et, al 1999) bodies drives the implementation of environmental management system in Ghana. Employees and customer demand seems to have no impact on environmental management system implementation in Ghana which seems to contradict (Clark, 1999; Graff, 1997 and Litskas, 1999).

\section{Implications of the Study}

From the study, since respondents made it clear that the most important factors driving the implementation of environmental management system in Ghana are; operational benefits, marketing opportunities, public relations/corporate image, conservation of natural resources and the potential for cost savings. There is therefore the need for organizations that have 
implemented environmental management systems in their operations to really catalogue the operational benefits and the other opportunities derived from EMS implementation in order to attract other firms to go into its implementation.

Indeed, it would be very strategic for organizations to include some environmental component in their quest to advertise and market their products and services in order to inform consumers on their commitment to environmental conservation and the effective management of natural resources. This will in turn drive environmental conscious consumers' attention to patronize their products thereby increasing sales as well as their public relations and image.

From the study it was also clear that the pressure from employees and customers seems to have very little influence as far as the implementation of environmental management system is concern. There is therefore the need for intensive internal awareness programme as well as increasing external stakeholders' communications through durbars and other marketing programmes to create some awareness on its benefits in order to drive its implementation.

This paper contributes to both practice and theory. For practice the results provide insights on the forces that drive environmental management systems implementation in a developing country such Ghana in the quest to achieve environmental excellence. Practitioners, including environmental representatives, can use some of the ideas presented in this paper to guide environmental management systems implementation. For theory, the results can be useful for more comprehensive studies on environmental management system implementation using more data from different developing countries. Such a study will provide more theoretical understanding of the driving forces of environmental management system implementations between research in developing and the developed nations.

\section{Limitations and Future Research Directions}

This study considered only ten key factors that drive environmental management system implementation. Apart from these factors there is the need to also look at the internal environment especially, skills of employees, top management support, training and education" etc. which also affect the implementation of these systems. Future studies can also look at the support of top management as well as the challenges they face in implementing environmental management systems. Additionally, most research studies assume that various driving forces are independent of each other and have no inter-relationships. This assumption can lead to deceptive conclusions as it is likely that some success factors are actually related to some others. It might therefore be equally important to study all the necessary factors together.

\section{Conclusions}

In assessing the driving forces for the implementation of environmental management system in Ghana, operational benefits, marketing opportunities, public relations/corporate image, conservation of natural resources and the potential for cost savings seems to be the top priorities driving the implementation of environmental management systems in Ghana. The rest are; competition, low insurance premium, enhanced quality of supply chains, pressure from regulatory bodies and employees. 
From the study, since respondents made it clear that the most important factors driving the implementation of environmental management system in Ghana are; operation benefits, marketing opportunities, public relations/corporate image, conservation of natural resources and the potential for cost savings, there is therefore the need for organizations that have implemented environmental management in their operations to really catalogue the operational benefits and other opportunities to attract other potential firms to emulate their steps.

It was also clear that the pressure from employees and customers seems to have very little influence as far as the implementation of environmental management system is concern. Hence there is the need for some sort of intensive internal awareness programme as well as increasing external stakeholders' communications through durbars and other marketing programmes.

\section{References}

Aven, T., \& Kristensen, V. (2005). Perspectives on risk: review and discussion of the basis for establishing a unified and holistic approach. Reliability Engineering and System Safety, 90(1), 1-14. http://dx.doi.org/10.1016/j.ress.2004.10.008

Babakri, K. A., Bennett, R. A., Rao, S., \& Franchetti, M. (2004). Recycling performance of firms before and after adoption of the ISO 14001 standard. Journal of Cleaner Production, 12, 633-37. http://dx.doi.org/10.1016/S0959-6526(03)00118-5

Ball, D. J. (2002). Environmental risk assessment and the intrusion of bias. Environment International, 28(6), 529-44. http://dx.doi.org/10.1016/S0160-4120(02)00061-2

Begley, R. (1995). Environmental ISO standards adds to management tasks: environmental systems get new scrutiny. Chemical Week, 157(45).

Berkhout, F., Hertin, J., Azzone, G., Carlens, J., Drunen, M., Jasch, C., Noci, G., Olsthoorn, X., Tyteca, D., Van Der Woerd, F., Wagner, M., Wehrmeyer, W., \& Wolf, O. (2001). Measuring the Environmental Performance of Industry. Final Report of Project MEPI (ENV4-CT97-0655), Environment and Climate Research Programme, European Commission (EC), Brussels.

Blackman, A., \& Guerrero, S. (2012). What drives voluntary eco-certification in Mexico?. Journal of Comparative Economics, 40(2), 256-68.http://dx.doi.org/10.1016/j.jce.2011.08.001

Chapman, C. B. (1997). Project risk analysis and management-PRAM the generic process. International Journal of Project Management, 15(5), 273-81. http://dx.doi.org/10.1016/S0263-7863(96)00079-8

Chavan, M. (2005). An appraisal of environmental management systems: a competitive advantage for small business. Management of Environmental Quality, 16(5), 444-63. http://dx.doi.org/10.1108/14777830510614321

Chaverri, R. L. (1999). Development of environmental performance indicators: the case of fish canning plants. Master's thesis, International Institute for Industrial Environmental Economics, Lund University, Lund.

Christina Diakaki, Evangelos Grigoroudis, Maria Stabouli, (2006). A risk assessment approach 
in selecting environmental performance indicators, Management of Environmental Quality: An International Journal, 17(2), 126-139. http://dx.doi.org/10.1108/14777830610650456

Christini, G., Fetsko, M., \& Hendrickson, C. (2004). Environmental management systems and ISO 14001 certification for construction firms. Journal of Construction Engineering and Management, 130(3), 330-36. http://dx.doi.org/10.1061/(ASCE)0733-9364(2004)130:3(330)

Christou, M., \& Amendale, A. (1998). How lessons learned from exercises can improve the quality of risk studies, in Mosleh, A. and Bari, R.A. (Eds), Proceedings of the 4th International Conference on Probabilistic Safety Assessment and Management (PSAM), New York, NY. PMCid:PMC22782.

Curkovic, S., Sroufe, R., \& Melnyk, S. (2005). Identifying the factors which affect the decision to attain ISO 14000. Energy, 30, 1387-407. http://dx.doi.org/10.1016/j.energy.2004.02.016

Everett, J., \& Neu, D. (2000). Ecological modernisation and the limits of environmental Accounting. Accounting Forum, 24, 5-29. http://dx.doi.org/10.1111/1467-6303.00027

Famiyeh, S, Kuttu, S, \& Bugri, A, E. (2014). Challenges of Environmental Management Systems Implementation in Ghanaian Firms. Journal of Sustainable Development, 7(1), 2014, ISSN 1913-9063 E-ISSN 1913-9071 Published by Canadian Center of Science and Education. http://dx.doi.org/10.5539/jsd.v7n1p105

Ghisellini, A., \& Thurston, D. L. (2005). Decision traps in ISO 14001 implementation process: case study results from Illinois certified companies. Journal of Cleaner Production, 13, 763-77. http://dx.doi.org/10.1016/j.jclepro.2004.02.042

Goodman, S., \& Stanger, C. (2002). Guide to Environmental Management Law and Practice 2002. Workplacelaw Network, Cambridge, pp. 51-5.

Gray, R. (2010). Is accounting for sustainability actually accounting for sustainability and how would we know? An exploration of narratives of organisations and the planet, Accounting, Organizations and Society, 35(1), 47-62. http://dx.doi.org/10.1016/j.aos.2009.04.006

Hamel, G., \& Prahalad, C. K. (1994). Competing for the Future, Harvard Business School Press, Boston, MA, pp. 24-32.

Hannagan, T. (1998). Management: concepts and practices, Financial Times, Pitman Publishing, pp. 567-9.

Hokstad, P., \& Steiro, T. (2006). Overall strategy for risk evaluation and priority setting of risk regulations. Reliability Engineering and System Safety, 91(1), 3575-86. http://dx.doi.org/10.1016/j.ress.2004.11.014

Hunt, C. B., \& Auster, E. R (1990). Proactive environmental management: avoiding the toxic trap. Sloan Management Review, 31(2), 7-18.

International Organisation for Standardisation (1999). ISO 14031 Environmental Management -Environmental Performance Evaluation-Standards and Guidelines, International Organisation for Standardisation, Geneva. 


\section{Macrothink}

Environmental Management and Sustainable Development

ISSN 2164-7682

2014, Vol. 3, No. 2

ISO (2004). ISO14001 Environmental Management System - Requirements with Guidance for Use, International Standards Organisation, Geneva.

Jesson, J., \& Andersen, S. (1994). Introduction to management requirements and toolkits, Journal of Cleaner Production, 2(2), 95-9. http://dx.doi.org/10.1016/0959-6526(94)90006-X

Karrer-Ru edi, E. (1998). Environmental Management Systems and Standards, Swiss Re America, New York, NY.

Khan, F. I., \& Haddara, M. M. (2003). Risk-based maintenance (RBM): a quantitative approach for maintenance/inspection scheduling and planning. Journal of Loss Prevention in the Process Industries, 16(6), 561-73. http://dx.doi.org/10.1016/j.jlp.2003.08.011.

Kolluru, R., Bartell, S., Pitblado, R., \& Stricoff, S. (1996). Risk Assessment and Management Handbook: for Environmental, Health and Safety Professionals, McGraw-Hill, New York, NY.PMid:15275250.

Lalley, E. (1982). Corporate Uncertainty and Risk Management, Risk Management Society Publishing, New York, NY.

Llewellyn, G. (1998). Strategic risk assessment-prioritising environmental protection. Journal of Hazardous Materials, 61(1-3), 279-86. http://dx.doi.org/10.1016/S0304-3894(98)00133-2

Marimon, F., Casadesus, M., \& Heras, I. (2010). Certification intensity level of the leading nations in ISO 9000 and ISO 14000 standards. International Journal of Quality \& Reliability Management, 27(9), 1002-20. http://dx.doi.org/10.1108/02656711011084800

Mauser, A. (2001). The Greening of Business, Environmental Management and Performance Evaluation: An Empirical Study in the Dutch Dairy Industry, Eburon Publishers, Delft.PMCid:PMC114329

Mckim, R. A. (1992). Risk management-back to basics. Cost Engineering, 34(12), 7-12.

Mullin, R., \& Sissel, K. (1995). Managers gear up for global standards. Chemical Week, 157, 65 .

Porter, M., \& van der Linde, C. (1995). Green and competitive: ending the stalemate, Harvard Business Review, September-October, pp. 121-34.

Potoski, M., \& Prakash, A. (2005). Green clubs and voluntary governance: ISO 14001 and firms' regulatory compliance, American Journal of Political Science, 49(2), 235-48. http://dx.doi.org/10.1111/j.0092-5853.2005.00120.x

Rahaman, A. S., Lawrence, S., \& Roper, J. (2004). Social and environmental reporting at the VRA: institutionalised legitimacy or legitimation crisis?. Critical Perspectives on Accounting, 15(1), 35-56. http://dx.doi.org/10.1016/S1045-2354(03)00005-4

Richard M. Fisher, (2003). Applying ISO 14001 as a business tool for campus sustainability: A case study from New Zealand. International Journal of Sustainability in Higher Education, 4(2), 138-150. http://dx.doi.org/10.1108/14676370310467159 
Shah, S. (2004). The role of facilities management. Essentialfm Report, 35, 6-8.

Slater, D., \& Jones, H. (1999). Environmental risk assessment and the environment agency. $\begin{array}{llll}\text { Journal of Hazardous } \quad \text { Materials, } & 65(1-2), & \text { 77-91. }\end{array}$ http://dx.doi.org/10.1016/S0304-3894(98)00256-8

Suresh Jain, \& Pallavi Pant, (2010). Environmental management systems for educational institutions: A case study of TERI University, New Delhi. International Journal of $\begin{array}{llll}\text { Sustainability in Higher } & \text { Education, 236-249. }\end{array}$ http://dx.doi.org/10.1108/14676371011058532

Tixier, J., Dusserre, G., Salvi, O., \& Gaston, D. (2002). Review of 62 risk analysis methodologies of industrial plants, Journal of Loss Prevention in the Process Industries, 15(4), 291-303. http://dx.doi.org/10.1016/S0950-4230(02)00008-6

United States Environmental Protection Agency (USEPA), http://www.epa.gov/nrmrl/std/lca/resources.html (accessed 01/02/14)

Von Bahr, B., Hanssen, O. J., Vold, M., Pott, G., Stoltenberg-Hansson, E., \& Steen, B. (2003). Experiences of environmental performance evaluation in the cement industry: data quality of environmental performance indicators as a limiting factor for benchmarking and rating, $\begin{array}{llll}\text { Journal of } \quad \text { Cleaner } & \text { 713-25. }\end{array}$ http://dx.doi.org/10.1016/S0959-6526(02)00126-9

Watson, M., \& Emery, A. R. T. (2004). Environmental management and auditing systems: the reality of environmental self-regulation. Managerial Auditing Journal, 19(7), 916-28. http://dx.doi.org/10.1108/02686900410549439

Whitelaw, K. (1997). ISO 14001 Environmental Systems Handbook, Butterworth-Heinemann, Oxford. PMCid:PMC231886

Zhang, Z. H., Shen, L. Y., Love, P. E. D., \& Treloar, G. (2000). A framework for implementing ISO 14001 in construction. Environmental Management \& Health, 11(2), 139-48. http://dx.doi.org/10.1108/09566160010321541

Zutshi, A., \& Sohal, A. (2003). Environmental management system auditing within Australasian companies, Managerial Auditing Journal, 18(8), 637-48. http://dx.doi.org/10.1108/02686900310495133

\section{Copyright Disclaimer}

Copyright for this article is retained by the author(s), with first publication rights granted to the journal.

This is an open-access article distributed under the terms and conditions of the Creative Commons Attribution license (http://creativecommons.org/licenses/by/3.0/). 